\title{
Pengaruh Pengetahuan Nasabah, Religiusitas Dan Margin Keuntungan Terhadap Keputusan Pengambilan Pembiayaan Murabahah Pada BPRS Lantabur Tebuireng Cabang Mojokerto
}

\author{
Nurul Dewi Andriani \\ Institut Pesantren KH. Abdul Chalim, Mojokerto, Indonesia \\ Email: andrinurullaini98@gmail.com \\ Lu'lu'il Maknuun \\ Institut Pesantren KH. Abdul Chalim, Mojokerto, Indonesia \\ Email : luluilmaknuun92@gmail.com \\ Moch Ichiyak Ulumudin \\ Institut Pesantren KH. Abdul Chalim, Mojokerto, Indonesia \\ Email : zakiculligehn@gmail.com
}

\begin{abstract}
Conventional financial institutions are indeed the choice of many people, but not everyone chooses these institutions. Some even prefer institutions with Islamic nuances to manage their finances, one of which is in terms of Murabaha financing. This is as found in the BPRS Lantabur Tebuireng, Mojokerto Branch. The motivation of this investigation was to determine the impact of customer knowledge, religiosity and profit margins on the decision to make murabahah financing at BPRS Lantabur Tebuireng, Mojokerto Branch. Quantitative method is the technique used in this research. The researcher uses murabahah financing customers as the population, and the sampling technique uses incidental sampling method which produces 79 people as samples. The strategy to find out the data is using multiple linear regression analysis method with SPSS 25 . The results of this study for the customer knowledge variable and the religiosity variable have no significant effect on decision making, while the profit margin variable has a significant influence on decision making. With the aim of customers taking murabaha financing, it is driven on the basis of capital needs and understanding of the level of profit margins.
\end{abstract}

Kata kunci: The Murabahah Financing Decision, Customer Knowledge, Religiosity, Profit Margins.

\begin{abstract}
Abstrak
Lembaga keuangan konvensional memang menjadi pilihan banyak orang namun tidak semua orang memilih lembaga tersebut. Sebagian malah lebih memilih lembaga bernuansakan islami untuk mengelola keuangan mereka salah satunya dalam hal pembiayaan Murabahah. Hal tersebut seperti yang terdapat di BPRS Lantabur Tebuireng Cabang Mojokerto. Motivasi penelitian ini adalah untuk mengetahui dampak Pengetahuan Nasabah, Religiusitas dan Margin Keuntungan terhadap Keputusan Pengambilan Pembiayaan murabahah di BPRS Lantabur Tebuireng Cabang Mojokerto. Metode kuantitatif adalah teknik yang diterapkan dalam penyelidikan ini. Peneliti menggunakan nasabah pendanaan murabahah sebagai populasi, dan prosedur pengujian memakai teknik insidental sampling yang menghasilkan 79 orang sebagai sampel. Strategi untuk mengetahui data menggunakan metode analisis regresi linier berganda dengan SPSS 25. Hasil penelitian ini untuk variabel pengetahuan nasabah dan variabel religiusitas tidak berpengaruh signifikan terhadap pengambilan keputusan, sedangkan variabel margin keuntungan mempunyai pengaruh signifikan terhadap pengambilan keputusan. Dengan tujuan nasabah mengambil pembiayaan murabahah didorong atas dasar kebutuhan modal dan
\end{abstract}


pemahaman tingkat margin keuntungan.

Kata kunci: Keputusan Pengambilan Pembiayaan Murabahah, Pengetahuan Nasabah, Religiusitas, Dan Margin Keuntungan.

\section{A. Pendahuluan}

lembaga moneter adalah komponen bisnis yang ditempati oleh administrasi keuangan, yang diidentifikasi dengan dana investasi dan kerangka kredit yang melayani masyarakat dalam kegiatan ekonomi. Salah satu lembaga keuangan yang diidentifikasi dengan kapasitas dan sirkulasi aset adalah bank syariah. ${ }^{1}$

Dalam sistem operasional, bank syariah menjalankan usaha yang menggunakan sistem bagi hasil, baik dalam hal penyediaan dana, pembiayaan maupun lainnya. ${ }^{2}$ Produk pembiyaan yang paling diminati nasabah adalah produk murabahah, karena praktis dan low risk. Pembiayaan murabahah adalah pembiayaan yang menggunakan akad penjualan dengan harga barang yang nyata ditambah marjin keuntungan yang disepakati.

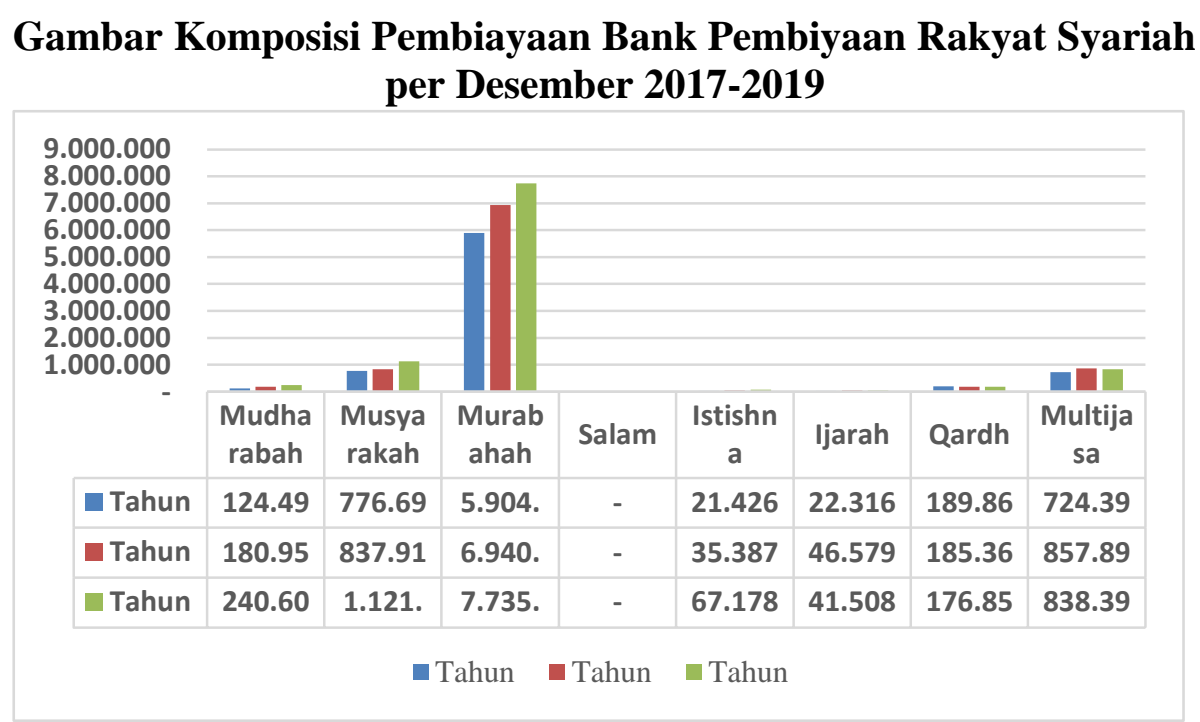

Sumber: Statistik Perbankan Syariah

Dari pengukuran keuangan Islam yang disajikan dalam grafik diatas terlihat bahwa nasabah mayoritas menggunakan pembiayaan murabahah dibanding pembiayaan yang lainnya. Dan setiap tahunnya mengalami peningkatan, mesikupun musyarakah mengalami peningkatan tiap tahun tetapi jumlah nasabah lebih tinggi yang melakukan pembiayaan murabahah dibandingkan dengan pembiayaan musyarakah.

Dalam kegiatan usaha Bank Pembiyaan Rakyat syariah menyediakan produk pembiayaan sesuai dengan prinsip-prinsip islam, salah satu adalah BPRS Lantabur Tebuireng

\footnotetext{
${ }^{1}$ Diambil dari Edukasi Keuangan, "Konsep dan Mekanisme Lembaga Keuangan Syraiah", dikitip pada 25 Mei 2020, jam 15:20, (http:// www.mag.co.id/ lembaga-keuangan-syariah/, diakses pada 18 Desember 2014)

2 Okta Rizki, "Persepsi Nasabah dan Margin Terhadap Keputusan Pengambilan Pembiayaan Griya pada Bank Syariah Mandiri KCP Teluk Betung Bandar Lampung", ( Universitas Islam Negeri Raden Intan Lampung, 2017), h. 4.
} 
Cabang Mojokerto. Banyaknya lembaga keuangan di kota Mojokerto akan memicu persaingan yang menawarkan pembiayaan dengan imbal bagi hasil yang beragam. Sering dengan perkembangan perekonomian masyarakat di Mojokerto BPRS Lantabur Tebuireng saat ini sedang berada ditahap perkembangan. Hal tersebut mendorong untuk meningkatkan strategi pemasaran agar menjaga kepercayaan nasabah terhadap BPRS Lantabur Tebuireng. Dan berdirinya BPRS Lantabur Tebuireng diharapakan dapat meningkat perekonomian masyarakat menegah kebawah di Mojokerto.

Produk-produk layanan yang ada di BPRS Lantabur yaitu tabungan deposito dan pembiayaan, untuk produk tabungannya ada tabungan mudharabah, tabungan pelajar, tabungan haji dan umroh, tabungan qurban. Sedangkan pembiayaannya ada pembiayaan mudharabah, musyarakah, qard, multijasa dan murabahah.

Banyaknya lembaga keuangan di kota Mojokerto akan memicu persaingan yang menawarkan pembiayaan dengan imbal bagi hasil yang beragam. Sering dengan perkembangan perekonomian masyarakat di Mojokerto BPRS Lantabur Tebuireng saat ini sedang berada ditahap perkembangan. Hal tersebut mendorong untuk meningkatkan strategi pemasaran agar menjaga kepercayaan nasabah terhadap BPRS Lantabur Tebuireng.

Rendahnya peminat bank syariah yang disebabkan masih banyaknya masyarakat yang sebenarnya tidak memahami kerangka dan item yang terdapat di bank syariah, standar yang diterapkan di bank syariah dan masyarakat pun masih mambandingkan bunga dengan margin yang ditetapkan di bank syariah. Hal tersebut disebabkan karena pemahaman yang rendah dan jika tidak memiliki informasi dan pemahaman yang luas akan mengakibatkan kecil kemungkinan untuk melakukan pembiayaan terhadap suatu produk.

Banyak masyarakat yang beragama islam masih menggunakan bank konvensional karena ketidaktahuan masyarakat cara bermuamalah yang baik dan benar dalam agama islam dan tidak sedikit pula orang yang tidak memahami sistem keuangan syariah, hal tersebut disebabkan pemahaman yang rendah salah satunya diakibatkan kurangnya sosialisai kepada masyarakat tentang perbankan syariah. ${ }^{3}$ Dengan demikian pentingnya pemahaman pengetahuan konsumen terhadap bank syariah, karena akan mengakibatkan kecil kemungkinan untuk melakukan pembiayaan terhadap suatu produk jika tidak memiliki informasi dan pemahaman yang luas.

Masyarakat memerlukan adanya informasi dan pengetahuan yang tidak hanya memahami bank dan sistem bagi hasil saja tetapi harus mengetahui produk, mekanisme produknya, dan istilah-istilah yang digunakan dalam bank syariah, karena semakain banyak

\footnotetext{
3 Wahyudi Akmal, "Analisis Faktor-faktor yang Mempengaruhi Keputusan Nasabah Menggunakan Pembiayaan Murabahah pada BPRS Surya cabang Kudus", (Sekolah Tinggi Agama Islam Negeri Kudus, 2017), h.5.
} 
pemahaman yang didapatkan semakin besar juga kemungkinan untuk melakukan pembiyaan. Maka tugas bank syariah tidak hanya memperluas promosi melalui media saja tetapi melakukan sosialisasi lagi yang lebih efektif sehingga pengetahuan masyarakat terhadap bank tidak hanya sebatas sistem bagi hasil.

Dalam memilihan produk bank syariah beberapa orang disebabkan oleh kepercayaan seperti agama yang dipercayainya. Mengaplikasikan tidakan religi pada kondisi masyarakat merupakan tidakan yang dapat mempengarui perilaku seseorang dalam kehidupan dan dipraktikkan pada kegiatan sehari-hari, baik dalam kehidupan sosial, ekonomi dan politik. Agama adalah jalan menuju cara hidup dari suatu iklim yang secara signifikan mempengaruhi perilaku pelanggan dan pada akhirnya dapat mempengaruhi dinamika. ${ }^{4}$ Dan hal tersebut berkaitan dengan pemahaman kegamaan seseorang terhadap sistem yang ada di bank syariah.

Pemahaman keagamaan seseorang terhadap sistem yang ada di bank syariah ialah pengetahuan yang diketahui seseorang tentang cara bermuamalah yang terdapat dalam agama yang diterapkan pada bank syariah, yang menggunakan prinsip berdasarkan hukum islam, seperti barang dan jasa yang dipakai harus jelas kehalalannya dan sistem bagi hasi tanpa riba.

Disisi lain masyarakat awam masih membandingkan pendapatan dan pendapatan bersih pada bank syariah, nasabah juga menilai pendapatan keseluruhan yang dikukuhkan dengan bank syariah sangat tinggi dibanding biaya yang dikukuhkan oleh bank konvensional. ${ }^{5}$ Setiap bank syariah mempromosikan jual beli murabahah dengan berbagai laba keuntungan yang berbeda-beda akan mempengaruhi munculnya berbagai alternatif untuk memilih bank bagi nasabah. ${ }^{6}$ Margin adalah keuntungan dalam pertukaran jual beli yang diselesaikan dan diperoleh oleh pedagang dan pembeli. Keuntungan diperoleh dari akad murabahah sebagai tingkat presentase yang ditentukan oleh bank.

\section{B. Landasan Teori}

\section{Perilaku Konsumen (Grand Theory)}

Sebelum pembeli memilih untuk membeli barang, awalnya akan memikirkan mulai dari nilai, kualitas dan kenyamanan. Pembeli akan memilih barang dagangan yang biayanya sesuai dengan anggaran, semakin tinggi nilai harga pokok produk, semakin lama pembeli menentukan pilihan untuk membeli. Begitupun sebaliknya jika harga tidak tinggi, maka konsumen akan cepat bertindak atau mengambil keputusan untuk

\footnotetext{
4 Wahyudi Akmal, "Analisis Faktor-faktor yang Mempengaruhi Keputusan Nasabah Menggunakan Pembiayaan Murabahah pada BPRS Surya cabang Kudus", (Sekolah Tinggi Agama Islam Negeri Kudus, 2017), h. 6.

${ }^{5}$ Ibid, h.9

${ }^{6}$ Ummu Sholihah, "Pengaruh Pengetahuan Nasabah, kualitas Pelayanan dan Margin Keuntungan Terhadap Keputusan Pengambilan Pembiayaan Murabahah", (Institut Agama Islam Negeri Surakarta, 2016), h. 2-3
} 
membeli.

Ketika sudah mempertimbangkannya konsumen akan memutuskan untuk memperoleh barang atau tidak, dan ketika sudah menetepkan untuk memperoleh barang, produk dan jasa, konsumen akan mengkosumsi atau menggunakan. Setelah mengkonsumsi konsumen akan mengevaluasi atau menilai barang apakah barang tersebut sesuai dengan harapan, kegunaannya. Dan akan menimbulkan sikap kepuasan atau ketidakpuasan. Perilaku konsemen ini sangat terat kaitannya dengan keputusan pengambilan pembiayaan. Perilaku konsumesn juga sangat mempengaruhi porses pengambilan keputusan.

\section{Keputusan Pembelian}

Sebelum mengambil keputusan konsumen akan mengenail permasalahannya atau kebutuhannya, seseorang menginginkan suatu barang, karena dipengarui kebutuhannya. Dan konsumen akan mempertimbangan apakah brang tersebut merupakan kebutuhan atau hanya keinginan. Setelah mengenali kebutuhannya, konsumen akan berusaha mendapatkan fakta tenang dibutuhkan tersebut. Konsumen akan mencari keterangan tentang barang yang dibutuhkan konsumen, memerlukan saran dari : keluarga, teman, tetangga dan iklan. ${ }^{7}$

Keputusan pengambialan merupakan tindakan atau sikap konsumen untuk mengevaluasi berbagai pilihan sebelum mengambil keputusan, untuk melakukan pembiayaan murabahah nasabah akan mencari masalahnya, apakah konsumen sangat membutuhkan produk atau barang yang akan dibeli, mencari tahu tentang produk yang kualitasnya bagus, dan harga yang seseuai dan konsumen akan mengevaluasi dan memecahkan masalahnya untuk memutusan pembelian.

Dan pada tahapan ini, konsumen dihadapkan dari berapa pilihan produk atau barang, konsumen harus mengevaluasi barang yang akan dipilih, barang mana yang memang sesuai kebutuhan. Setelah mengevaluasi dan cocok untuk dibeli konsumen akan mengambil keputusan untuk membeli barang yang dipilihnya dan sesuai kebutuhan dan keinginannya. Setelah melakukan pembelian konsumen akan menilai produk atau barangyang telah dibeli konsumen apakah menimbulkan kepuasan atau ketidakpuasan. Konsumen akan menentukan kepuasannya terletak pada presentase atau harapan yang diterima atas barang yang datang.

7 Okta Rizki, "Persepsi Nasabah dan Margin Terhadap Keputusan Pengambilan Pembiayaan Griya pada Bank Syariah Mandiri KCP Teluk Betung Bandar Lampung", ( Universitas Islam Negeri Raden Intan Lampung, 2017), h. 42. 


\section{Pembiayaan Murabahah dan Pengetahuan Nasabah}

Pembiayaan murabahah adalah kesepakatan pertukaran dengan aturan jual beli barang dagangan secara angsur dengan menambahkan margin sebagai keuntungan yang diperoleh bank, pembiyaan murabahah yang bertujan untuk membiayai pembelian barang yang dibutuhkan oleh nasabah. pembiayaan murabahah ini produk pembiyaan bertujuan untuk memenuhi kebutuhan.

Pengetahuan konsumen merupakan pernyataan perihal beragam produk dan informasi lainnya yang bersangkutan dengan manfaat konsumen di dalam pasar. Pengetahuan konsumen dibagi dalam beberapa bagian, yaitu pengetahuan produk, penegtahuan pembelian, dan pengetahuan pemakaian. Pengetahuan nasabah merupakan informasi yang dipahami tentang produk- produk dan jasa yang ada di bank serta pengetahuan lain yang berkaitan dengan fungsinya sebagai nasabah.

Menurut Peter dan Olson dalam penelitian Saidah Mushoffa Rohmah memeparkan bahwa informasi barang dibagi menjadi tiga jenis, yaitu: informasi tentang tingkat baik buruk atau sifat barang, informasi tentang keutamaan barang, dan informasi tentang kesenangan yang diberikan oleh barang kepada pembeli atau pelanggan. ${ }^{8}$

\section{Religiusitas}

Religiusitas merupakan sikap seseorang dalam ketaatannya terhadap agamanya dalam menjalankan kehidupannya agar mendapatkan kebahagian dunia akhirat. Dan dalam berbagai sisi kehidupan bersikap hati-hati dan memperhatikan syariah islam dan keharamannya. Religiusitas merupakan keyakinan, kepercayaan dan penghayatan yang berhubungan antara manusia dengan pencipta-Nya. Penghayatan tersebut akan diamalkan dalam kehidupan sehari-hari seperti bermuamalah.

Dalam memilihan produk bank syariah beberapa orang disebabkan oleh kepercayaan, Mengaplikasikan tidakan religi pada kondisi masyarakat merupakan tidakan yang dapat mempengarui perilaku seseorang dalam kehidupan dan dipraktikkan pada kegiatan sehari-hari. Agama merupakan kunci budaya sebuah lingkungan yang sangat mempengaruhi perilaku konsumen dan pada akrinya dapat mempengaruhi pengambilan keputusan. ${ }^{9}$ Dan hal tersebut berkaitan dengan

\footnotetext{
8 Saidah Mushoffa Rohmah, "Pengaruh Pengetahuan, Promosi dan Kualitas Pelayanan Terhadap Keputusan Pembiayaan Murabahah pada Anggota BMT Buana Mulur Sukoharjo", (Institut Agama Islam Negeri Surakarta,2017), h.16.

9 Wahyudi Akmal, "Analisis Faktor-faktor yang Mempengaruhi Keputusan Nasabah Menggunakan Pembiayaan Murabahah pada BPRS Surya cabang Kudus", (Sekolah Tinggi Agama Islam Negeri Kudus, 2017), h. 6.
} 
pemahaman kegamaan seseorang terhadap sistem yang ada di bank syariah.

Pemahaman keagamaan seseorang terhadap sistem yang ada di bank syariah ialah pengetahuan yang diketahui seseorang tentang cara bermuamalah yang terdapat dalam agama yang diterapkan pada bank syariah, yang menggunakan prinsip berdasarkan hukum islam, seperti barang dan jasa yang dipakai harus jelas kehalalannya dan sistem bagi hasi tanpa riba.

\section{Margin Keuntungan}

Margin merupakan keuntungan dalam persetujuan jual beli yang diselesaikan dan diperoleh oleh pedagang dan pembeli. Keuntungan diperoleh dari manfaat dari kontrak murabahah sebagai presentase yang ditentukan oleh bank. Berdasarkan penelitian Erlina, penentuan nilai margin yang rendah dan sesuai dengan kesepahaman antara kedua belah pihak, kecepatan bank dalam melayani pengambilan pembiayaan, dan syarat-syarat yang mudah, serta cepatnya penerimaan aplikasi pembiayaan, sehingga nasabah akan terdorong untuk memutuskan melakukan pembiayaan. ${ }^{10}$ Dari uraian tersebut semakin rendah nilai margin, dan penentuannya sesuai kesepakatan, serta memudahkan nasabah dalam melakukan pembiayaan, maka semakin cepat nasabah mengambil keputusan untuk melakukan pembiayaan.

Rumus dalam menentukan Margin Keuntungan yaitu sebagai berikut:

$$
\text { Margin keuntungan }=\frac{\text { Pendapatan jual }-H P P}{\text { Total pendapatan ope rasional utama }}
$$

Margin keuntungan merupakan persentase yang diperoleh dari penadapatan penjualan atas produk atau barang dikurang harga pokok penjualan dibagi dengan pendapatan operasional atau pendapatan penjualan. Harga peroleh dari biayaa yang dikeluarkan yang berkaitan dengan proses produksi barang seperti biaya material, gaji tenaga kerja dan sebagainya.

\section{Metode Penelitian}

Dalam penelitian ini memanfaatkan teknik kuantitatif. Terlebih lagi, wawasan sebagai instrumen untuk menganalisis. Menurut Sugiyono, teknik kuantitatif dapat diartikan sebagai strategi pengujian tergantung pada cara berpikir positivisme yang digunakan untuk melihat populasi atau sampel untuk mengumpulkan informasi dengan

10 Erlina Agustin, "Pengaruh Kualitas Pelayanan, Religiusitas dan Margin Keuntungan Terhadap Keputusan Anggota Memilih Pembiyaan Murabahah di Koprasi Simpan Pinjam Pembiayaan Syariah Soyo Mulyo Watulimo Trenggalek", (Institut Agama Islam Negri Tulungagung,2018), h.10. 
menggunakan instrumen penelitian. Sepenuhnya bermaksud menggambarkan dan menguji spekulasi yang ditetapkan.

Variabel penelitian adalah segala sesuatu yang berubah menjadi objek pengamatan yang dikendalikan oleh analis untuk dikonsentrasikan sehingga diperoleh data tentangnya, kemudian, ditarik kesimpulan. Penelitian ini memakai variabel Pengetahuan Nasabah, Religiusitas dan Margin Keuntungan sebagai variabel indepenen. Dan Keputusan pengambilan Pembiayaan Murabahah sebagai variabel dependen.

Objek dalam penelitian ini menggunakan nasabah yang melakukan pembiayaan murabahah di BPRS Lantabur Tebuireng Cabang Mojokerto, Populasi dalam penelitian ini adalah keseluruhan nasabah yang mempunyai pembiayaan murabahah di BPRS Lantabur Tebuireng Cabang Mojokerto yang berjumlah 370 nasabah. Dengan teknik pengumpulan data mengunakan kuesioner dan strategi pengaambilan sampel dalam penelitian ini menggunakan teknik nonprobability sampling metode purposive sampling Rumus Slovin. Berdasarkan data yang diperoleh, jumlah sampel yang diteliti adalah 79 orang nasabah.

Metode analisis data dalam peneitian ini menggunakan analisis regresi berganda, sebelum melakukan analisis regresi berganda ada asumsi yang harus dipenuhi dalam model regresi melalui rangkaia uji asumsi klasik, dan alat untuk menganalisis yaitu deengan menggunakan SPSS (Statistical Package for Social Science).

\section{Hasil dan Pembahasan}

\section{Uji Parsial}

Terdapat dua dasar pengambilan keputusan uji parsial yang menjadi acuan untuk mencari hasil, jika nilai signifikansi lebih besar dari 0,05 maka variabel bebas berpengaruh signifikan terhadap variabel terikat, cara membandingkan $t_{\text {hitung }}$ dengan $t$ tabel, jika $t_{\text {hitung }}>t_{\text {tabel }}$ sampai batas tertentu variabel bebas berpengaruh besar pada variabel terikat. Rumus mencari $\mathrm{t}_{\text {tabel }}=\left(\frac{\alpha}{2} ; n-k-1\right)=(0,05 / 2 ; 79-3-1)=(0,025 ; 75)$ = 1,992 maka menghasilkan:

\section{Tabel Uji Parsial}

Coefficients ${ }^{a}$

\begin{tabular}{|c|c|c|c|c|c|c|}
\hline & & \multicolumn{2}{|c|}{$\begin{array}{c}\text { Unstandardized } \\
\text { Coefficients }\end{array}$} & \multirow{2}{*}{$\begin{array}{c}\text { Standardized } \\
\text { Coefficients } \\
\text { Beta } \\
\end{array}$} & \multirow[b]{2}{*}{$\mathrm{t}$} & \multirow[b]{2}{*}{ Sig. } \\
\hline \multicolumn{2}{|c|}{ Model } & B & Std. Error & & & \\
\hline \multirow[t]{2}{*}{1} & (Constant) & 4.517 & 2.343 & & 1.928 & .058 \\
\hline & Pengetahuan Nasabah & .146 & .080 & .205 & 1.836 & .070 \\
\hline
\end{tabular}


Nurul Dewi Andriani, dkk : Pengaruh Pengetahuan Nasabah ...

\begin{tabular}{|l|l|r|r|r|r|r|}
\hline \multirow{2}{*}{} & Religiusits & .004 & .085 & .007 & .052 & .958 \\
\cline { 2 - 6 } & Margin Keuntungan & .339 & .080 & .555 & 4.259 & .000 \\
\hline
\end{tabular}

Sumber olah SPSS

a. Pengaruh pengetahauan nasabah terhadap keputusan pengambilan pembiayaan murabahah

Hasil dari uji parsial, pengetahuan nasabah tidak memiliki dampak penting pada Keputusan Pengambilan Pembiayaan Murabahah Di BPRS Lantabur Tebuireng Cabang Mojokerto, dengan nilai $(1,836<1,992)$ dengan tarif signifikansi 0,070 >0,05.

Dari hasil kuesioner jawaban responden, dampak yang mengakibatkan nasabah menetapkan untuk menggunakan pembiayaan murabahah atas dasar untuk mencukupi kebutuhan modal atau konsumtif. Menurut Kotler dalam penelitian Siti Aisyah memaparkan bahwa aspek yang memotivasi keputusan pembelian salah satunya adalah faktor psikologis yaitu faktor motivasi, persepsi, pembelajaran, serta keyakinan dan sikap. Motivasi adalah dorongan yang muncul dalam diri seseorang untuk melakukan suatu tindakan atau kebutuhan. ${ }^{11}$ Jadi apabila seseorang melakukan pembiayaan didorong atas dasar kebutuhan, maka konsumen akan berusaha memuaskan kebutuhannya agar terpenuhi.

b. Pengaruh religiusitas terhadap keputusan pengambilan pembiayaan murabahah

Berdasarkan hasil penelitian menunjukan bahwa religiusitas tidak berpengaruh signifikan dengan nilai $t_{\text {hitung }}<t_{\text {tabel }}(0,052<1,992)$ dengan tarif signifikansi sebesar 0,958 > 0,05. Menurut penelitian Ery dan Hardiwinoto bahwa tidak ada pengaruh antara religiusitas dengan sikap nasabah dalam mengambil pendanaan di bank syariah, sebab konsumen yang memiliki tingkat religiusitas yang tidak dapat disangkal tidak akan mempengaruhi pilihan dalam memilih pembiayaan. Dapat disimpulkan bahwa religiusitas tidak menjadi faktor langsung, karena pemahaman sitem dan prinsip syariah yang digunakan di bank syariah tidak dilihat dari tingkat religiusitas seseorang. c. Pengaruh margin keuntungan terhadap keputusan pengambilan pembiayaan murabahah

Margin keuntungan memperoleh hasil signifikan dengan nilai $t_{\text {hitung }}>t_{\text {tabel }}(4,259$ $>1,992$ ) dan taraf kepercayaan $0,000<0,05$. Ulasan ini diperkuat oleh analisa yang dilakukan Ummi Sholihah, semakin paham nasabah terhadap pendapatan bersih, semakin tinggi pula kepercayaan untuk mengajukan pembiayaan murabahah. Berbeda

11 Siti Aisyah, "Pengaruh Citra Merek DBL Terhadap Keputusan Pembalian Kaos Olahraga Basket di DBL Store Surabaya", (Universitas Islam Negeri Sunan Ampel Surabaya,2017), h.21. 
dengan penelitian Erlina Agustin manyatakan semakin rengah tingkat margin keuntungan maka akan semakin tinggi tingkat keputuasan memilih pembiayaan murabahah.

Dapat disimpulkan bahwa semakin paham penentuan dan perhitungan margin keuntuangan dan tingkat margin yang tidak memberatkan maka akan semakin tinggi juga kepercayaan nasabah untuk mengajukan pembaiayaan murabahah pada BPRS Lantabur Tebuireng cabang Mojokerto.

\section{Uji Simultan}

Pengaturannya adalah bahwa dengan nilai signifikan $<0,05$, semua variabel bebas secara keseluruhan berpengaruh signifikan terhadap variabel terikat. Untuk membandingkan $F_{\text {hitung }}$ dengan $F_{\text {tabel, }}$ jika $F_{\text {hitung }}>F_{\text {tabel }}$ maka secara bersamaan variabel bebas berdampak nyata pada variabel terikat. Sebelum menyimpulkan berpengaruh atau tidaknya, untuk terlebih dahulu menentukan $\mathrm{F}_{\text {tabel. }}$ Rumum mencari $\mathrm{F}_{\text {tabel }}=(\mathrm{k} ; \mathrm{n}$ $\mathrm{k})=(3 ; 79-3)=(3 ; 76)=2,72$

Tabel Uji Simultan

ANOVA $^{\mathrm{a}}$

\begin{tabular}{|l|l|r|r|r|r|r|}
\hline \multicolumn{2}{|l|}{ Model } & Sum of Squares & Df & Mean Square & \multicolumn{1}{c|}{ F } & \multicolumn{1}{c|}{ Sig. } \\
\hline \multirow{3}{*}{1} & Regression & 159.552 & 3 & 53.184 & 25.226 & $.000^{\mathrm{b}}$ \\
\cline { 2 - 7 } & Residual & 158.119 & 75 & 2.108 & & \\
\cline { 2 - 7 } & Total & 317.671 & 78 & & & \\
\hline
\end{tabular}

Sumber olah SPSS

Dapat dilihat dari tabel diatas maka nilai signifikan variabel bebas secara bersamaa 0,000 lebih kecil dari 0,05 dan $F_{\text {hitung }}$ 25,226 lebih besar dari 2,72, sehingga variabel bebas berpengaruh terhadap variabel terikat.

\section{E. Kesimpulan}

Dari hasil analisis data, pemaparan yang telah dijelaskan dapat disimpulkan dari penelitian ini bahwa varabel Pengetahuan Nasabah, Religiusitas, Margin keuntungan secara parsial Tidak Berpengaruh besar pada Keputusan Pengambialan Pembiayaan Murabahah pada BPRS Lantabur Tebuireng Cabang Mojokerto namun, Pengaruh Pengetahuan Nasabah, Religiusitas dan Margin Keuntungan secara simultan berpengaruh terhadap Keputusan Pengambilan Pembiayaan Murabahah pada BPRS Lantabur Tebuireng Cabang Mojokerto. 


\section{Daftar Pustaka}

Antonio, Muhammad Syafii, Bank Syariah Dari Teori ke Praktek, Jakarta: Gema Insani, 2001. Sugiyono, Metode Penelitian Kuantitatif, Bandung: Alfabeta, 2019.

Amstrong, Gary, dan Philip Kotler, Prinsip- Prinsip Pemasaran Jilid 2, Jakarta: Erlangga, 2018.

Engel, F. James, Blackwell, D, Roger, Miniard, Paul, Perilaku konsumen, Edisi 6 Jilid 1, Jakarta: Binarupa Aksara, 2002.

Karim, Adiwarman, Analisis Fiqih dan Keuangan, Jakarta: Rajawali Press, 2011.

Kotler, P dan Kevin Keller, Prinsip-Prinsip Pemasaran jilid 1, Jakarta: PT. Macanan Jaya Cemerlang, 2009.

Schiffman, Leon G, dan Leslie Lazar Kanuk, Perilaku Konsumen, Ahli Bahasa Zoelkifli Kasip, Jakarta: PT. Indeks, 2005.

Setiadi, Nugroho. J, Perilaku Konsumen, Salatiga: C.V Andi, 2003.

Sugiyono, Metode Penelitian Kuantitatif, Bandung: Alfabeta, 2019.

Wiroso, Penghimpunan Dana dan Distribusi Hasil Usaha Bank Syariah, Jakarta: PT. Grasindo, 2005. 